\title{
Relative Densities of Synaptic and Extrasynaptic GABA Receptors on Cerebellar Granule Cells As Determined by a Quantitative Immunogold Method
}

\author{
Zoltan Nusser,, J. David B. Roberts, ${ }^{1}$ Agnes Baude, ${ }^{1}$ J. Grayson Richards, ${ }^{2}$ and Peter Somogyi ${ }^{1}$ \\ 'Medical Research Council, Anatomical Neuropharmacology Unit, University of Oxford, Oxford OX1 3TH, United \\ Kingdom, and 2Pharmaceutical Research Department, F. Hoffman-La Roche and Co. Ltd., CH-4002 Basel, \\ Switzerland
}

Ion channels gated by the inhibitory neurotransmitter $\gamma$-aminobutyric acid (GABA) are thought to be located in synaptic junctions, but they have also been found throughout the somatodendritic membrane of neurons independent of synapses. To test whether synaptic junctions are enriched in $\mathrm{GABA}_{A}$ receptors, and to determine the relative densities of synaptic and extrasynaptic receptors, the $\alpha 1$ and $\beta 2 / 3$ subunits of the $\mathrm{GABA}_{A}$ receptor were localized on cerebellar granule cells using a postembedding immunogold method in cats. Immunoparticle density for the $\alpha 1$ and $\beta 2 / 3$ subunits was approximately 230 and 180 times more concentrated, respectively, in the synaptic junction made by GABAergic Golgi cell terminals with granule cell dendrites than on the extrasynaptic somatic membrane. Quantification of immunoreactivity revealed one synapse population for the $\beta 2 / 3$, but appeared to show two populations for the $\alpha 1$ subunit immunoreactivity. The concentration of these subunits on somatic membrane was significantly lower than on the extrasynaptic dendritic membrane. Synaptic junctions with glutamatergic mossy fiber terminals were immunonegative. The results demonstrate that granule cells receiving GABAergic synapses at a restricted location on their distal dendrites exhibit a highly compartmentalized distribution of $\mathrm{GABA}_{A}$ receptor in their plasma membrane.

[Key words: ion channels, GABA $A_{A}$ receptor, synapse, cerebellum, immunocytochemistry, inhibition]

The fast onset and rise time of $\mathrm{GABA}_{\mathrm{A}}$ receptor-mediated inhibitory postsynaptic currents indicate that synaptically activated GABA-gated chloride channels are close to the GABA release site (Edwards et al., 1990; Konnerth et al., 1990; Otis and Mody, 1992; Llano and Gerschenfeld, 1993; De Koninck and Mody, 1994; Puia et al., 1994; Soltesz and Mody, 1994). A quantum of GABA molecules has been calculated to activate approximately 10-60 channels during synaptic transmission (Edwards et al., 1990; De Koninck and Mody, 1994; Soltesz and Mody, 1994). Neurotransmitter receptors are thought to be located in

Received Aug. 31, 1994; revised Oct. 25, 1994; accepted Oct. 31, 1994.

We are grateful to Miss D. Latawiec for excellent technical assistance and to Mr. F. Kennedy and Mr. P. Jays for photographic assistance. Z.N. is supported by a grant from Merck Sharp and Dohme Ltd. A.B. was supported by the Commission of European Communities, HCM Fellowship ERB CHBICT 920036.

Copyright (c) 1995 Society for Neuroscience $0270-6474 / 95 / 152948-13 \$ 05.00 / 0$ the anatomically defined synaptic junction. However, when $\mathrm{GABA}_{\mathrm{A}}$ receptors were localized at the electron microscopic level they were found throughout the neuronal surface, independent of synaptic contacts (Richards et al., 1987; De Blas et al., 1988; Meinecke et al., 1989; Somogyi, 1989; Somogyi et al., 1989; Yazulla et al., 1989; Soltesz et al., 1990; Waldvogel et al., 1990; Hansen et al., 1991; Greferath et al., 1993; Spreafico et al., 1993a). The extrasynaptic location of receptors has been confirmed by outside-out patch-clamp recordings of single GABAgated chloride channels isolated from the soma and dendrites of a variety of neurons (Cull-Candy and Ogden, 1985; Edwards et al., 1990; Sakmann, 1992; Llano and Gerschenfeld, 1993; Kaneda et al., 1994; Macdonald and Olsen, 1994; Puia et al., 1994).

In theory, electron microscopic immunocytochemistry should provide the resolution for the precise localization of neurotransmitter receptors, and $\mathrm{GABA}_{\mathrm{A}}$ receptors have been localized in the CNS. Although in addition to extrasynaptic sites, synaptic receptor localization has also been reported (Richards et al., 1987; De Blas et al., 1988; Meinecke et al., 1989; Somogyi, 1989; Somogyi et al., 1989; Yazulla et al., 1989; Soltesz et al., 1990, Waldvogel et al., 1990; Greferath et al., 1993; Spreafico et al., 1993a), all studies in the brain used immunoperoxidase methods employing a diffusible marker which provides poor resolution and cannot be easily quantified. The results reported with the immunoperoxidase method did not indicate an enrichment of $\mathrm{GABA}_{\mathrm{A}}$ receptor immunoreactivity in synaptic junctions. Furthermore, the diffusion of immunoperoxidase end-product may result in a secondary deposition of label, that was originally produced at extrasynaptic sites, in synaptic location. For example, the metabotropic glu tamate receptor was found to be preferentially located at perisynaptic plasma membrane using a particulate immunogold marker (Baude et al., 1993; Nusser et al., 1994), but when it was localized using the diffusible peroxidase product the whole synaptic specialization appeared labeled (Martin et al., 1992; Gorcs et al., 1993). This example also shows that different neurotransmitter receptors, apparently activated by transmitter from the same nerve terminal, may be localized in a restricted area of the postsynaptic membrane. Thus, due to the above mentioned technical limitations, the precise distribution of $\mathrm{GABA}_{A}$ receptors has remained uncertain.

The postembedding immunogold method offers several advantages for the localization of transmitter receptors. First, it provides a nondiffusible label with a resolution of about $20 \mathrm{~nm}$ which is suitable to define receptors in the synaptic junction 
(Triller et al., 1985, 1986; Hansen et al., 1991; Baude et al., 1993; Nusser et al., 1994, 1995). Second, the particulate marker can be quantified (Fujimoto, 1993; Nusser et al., 1994). Third, since the surface of the electron microscopic sections are directly in contact with the antibodies, there is no difference between different tissue elements in their access to antibodies, making quantitative comparisons possible. Therefore, we applied the postembedding method to study how GABA $_{A}$ receptors were distributed on the neuronal surface and to what degree receptors were expressed at different densities in relation to synaptic junctions. The cerebellar cortex was chosen for this study because the origin and the position of GABAergic synapses are well known and both the pre- and postsynaptic elements can be easily identified. Cerebellar granule cells, the main focus of this study, form a relatively homogeneous neuronal population with a simple synaptic organization. They are activated by glutamatergic mossy fibers and receive GABA from local Golgi cells only on their distal dendrites (Ottersen and Storm-Mathisen, 1984; Mugnaini and Oertel, 1985; Ottersen et al., 1988). However, they express $\mathrm{GABA}_{\mathrm{A}}$ receptor protein on their extrasynaptic somatic, dendritic, and synaptic membranes (Somogyi et al., 1989), making quantitative comparisons of different compartments possible.

\section{Materials and Methods}

Preparation of tissue. Two adult female cats $(2 \mathrm{~kg}$ body weight) were anesthetized intramuscularly with $0.6 \mathrm{ml}$ of a mixture containing one part Rompun $(20 \mathrm{mg} / \mathrm{ml}$ xylasin $)$ and two parts Vetalar $(100 \mathrm{mg} / \mathrm{ml}$ ketamine). The cats were perfused through the heart, first with cold artificial cerebrospinal fluid for $1 \mathrm{~min}$, then with ice-cold fixative containing $4 \%$ paraformaldehyde, $0.05 \%$ glutaraldehyde, and $\sim 0.2 \%$ picric acid dissolved in $0.1 \mathrm{M}$ phosphate huffer (PB, $\mathrm{pH}=7.4$ ) for $7 \mathrm{~min}$ (Somogyi et al., 1989). The brain was removed, and small blocks from the cerebellum were cut out and washed well. Then the blocks for preembedding immunocytochemical experiments were immersed in $10 \%$ sucrose solution in $0.1 \mathrm{M} \mathrm{PB}$ for $1 \mathrm{hr}$, followed by $20 \%$ sucrose until they sank. To facilitate the penetration of reagents, the blocks were fruzen in liquid $\mathrm{N}_{2}$ then thawed in $0.1 \mathrm{M} \mathrm{PB}$, and $70 \mu \mathrm{m}$ thick sections were cut on a Vibratome.

Antibodies and controls. Antibody specificity has already been described for monoclonal antibodies bd-24 and bd-17 (Haring et al., 1985; Schoch et al., 1985), for the polyclonal antibody to GABA, No. 9 (Hodgson et al., 1985), and for the polyclonal antibody against synapsin I (Naito and Ueda, 1981).

Method specificity was tested as follows. Immunoreactivity could not be detected when the antibodies (bd-24 and bd-17 affinity-purified monoclonal antibodies, GABA No. 9 and synapsin polyclonal antibodies) were either omitted or replaced by $5 \%$ normal mouse or rabbit serum. Using another monoclonal antibody, raised to somatostatin (Vincent et al., 1985), no plasma membrane labeling was observed with our methods, demonstrating that the labeling observed at the plasma membrane is due to the anti-receptor antibodies (bd-24 and bd-17).

Pre-embedding immunocytochemistry. Normal rabbit serum was used in Tris-buffered saline $(\mathrm{pH}=7.4)$ as blocking solution for $1 \mathrm{hr}$, then the purified primary antibodies were used at a protein concentration of $0.04 \mu \mathrm{g} / \mathrm{ml}$ and $6.6 \mu \mathrm{g} / \mathrm{ml}$ for bd-24 and bd-17, respectively. After washing, the sections were incubated for $90 \mathrm{~min}$ in goat anti-mouse IgG coupled to $1.4 \mathrm{~nm}$ gold (Nanogold, Nanoprobes Inc., Stony Brook, NY) Gold particles were silver enhanced for $16 \mathrm{~min}$ with HQ Silver kit as described by the manufacturer (Nanoprobes Inc.). Sections were then routinely processed for electron microscopic examination (Somogyi et al., 1989; Baude et al., 1993).

Freeze substitution and Lowicryl embedding. A similar method was used as reported earlier (Baude et al., 1993). Briefly, after perfusion the blocks were washed in $0.1 \mathrm{M}$ PB followed by vibratome sectioning (500 $\mu \mathrm{m}$ ) and washing with $0.1 \mathrm{M}$ PB overnight. The sections were placed into $1 \mathrm{M}$ sucrose solution in $0.1 \mathrm{M}$ PB for $2 \mathrm{hr}$ for cryoprotection before they were slammed to a polished copper block cooled with liquid $\mathrm{N}_{2}$ (Reichert MM80 E). Small blocks were trimmed from the cryofixed tissue and transferred to a Leica CS Auto at $-80^{\circ} \mathrm{C}$ where freeze-sub- stitution proceeded as follows: methanol at $-80^{\circ} \mathrm{C}$ for $36 \mathrm{hr}$; the temperature was increased by $10^{\circ} \mathrm{C} / \mathrm{hr}$ to $-50^{\circ} \mathrm{C}$ and all the following steps were conducted at this temperature; methanol/Lowicryl HM20 (Chemische Werke Lowi GMBH and Co.) 1:1 $90 \mathrm{~min}, 1: 290 \mathrm{~min}$; neat Lowicryl $90 \mathrm{~min}$; fresh Lowicryl overnight; after embedding, polymerization in fresh Lowicryl under UV light for $48 \mathrm{hr}$.

Postembedding immunohistochemistry. Iltrathin sections $(90 \mathrm{~nm})$ from Lowicryl-embedded blocks were incubated on drops of blocking solution for $30 \mathrm{~min}$. The blocking solution consisted of $0.1 \mathrm{M}$ phosphatc-buffercd salinc containing $0.8 \%$ ovalbumin, $0.1 \%$ cold-water fish skin gelatin (Sigma, Pool, UK), and 5\% fetal calf serum. The primary and secondary antibodies were also made up in this solution. Two methods were used: (1) double immunostaining for receptors (antibodies diluted $0.26-0.52$ and $10-20 \mu \mathrm{g}$ protein $/ \mathrm{ml}$ for the monoclonal antibodies bd-24 and bd-17, respectively) and for GABA (antiserum diluted 1:3000-1:4000) on the same ultrathin section; and (2) alternating serial sections incubated either for receptor or GABA or for receptor or synapsin on separate grids.

Sections were incubated in primary antibodies overnight at room temperature. After washing, the sections were incubated for $90 \mathrm{~min}$ with a mixture of goat anti-mouse IgG coupled to $1.4 \mathrm{~nm}$ gold (Nanogold, Nanoprobes Inc.) for receptors and goat anti-rabbit IgG coupled to 15 $\mathrm{nm}$ gold (BioClinical Services Ltd., Cardiff, UK) for GABA or synapsin. Sections were washed in $0.1 \mathrm{M}$ PB then transferred to $2 \%$ glutaraldehyde in PB for 2 min. After washing with ultrapure water, the $1.4 \mathrm{~nm}$ gold-containing sections were silver enhanced with HQ silver kit (Nanoprobes) for $4 \mathrm{~min}$. Standard uranyl acetate and lead staining were used.

Measurements of $G A B A_{A}$ receptor immunoreactivity following postembedding immunogold localization. Measurements were taken either from sections double immunostained for $\mathrm{GABA}_{\mathrm{A}}$ receptor and GABA, or from serial immunostained sections for $\mathrm{GABA}_{A}$ receptor or either GABA or synapsin on different grids. The preservation of tissue and immunoreactivity was uneven within the slam-frozen blocks of tissue; therefore, we defined a reproducible method of sampling. Wc scanncd systematically the well preserved strip until the first GABAergic Golgi cell terminal was observed in a glomerulus, and determined whether there was a synaptic junction between this Golgi cell terminal and a granule cell dendrite. Next we determined whether the glomerulus was in an area immunoreactive for receptor. An arbitrary criterion at least two gold particles in a synaptic junction was used as the lower cut of value for accepting the area as immunoreactive. This synapse was placed in the middle of the photograph and a $4 \times 3 \mu \mathrm{m}$ area was analyzed at a final magnification of $46,600 \times$. If there was no granule cell somatic membrane present in the field of view, the somatic membrane of the nearest granule cell to our synapse was photographed. The profiles within this rectangle were analyzed. Four different profiles were distinguished on the basis of their morphology, localization, size, and GABA and synapsin reactivity. The appearance of the slamfrozen, freeze-substituted, Lowicryl-embedded tissue is different from osmium-treated, epoxy resin-embedded tissue. The criteria used to differentiate the cellular profiles was as follows. (1) Golgi terminals: immunoreactive for GABA and synapsin; mainly located at the periphery of the glomeruli; smaller size compared to mossy terminals; vesicles are generally visible. (2) Mossy terminals: immunonegative for GABA but immunopositive for synapsin; large number of mitochondria; vesicles are generally visible; large size; mainly located in the middle of the glomeruli. (3) Granule cell dendrites: GABA and synapsin immunonegative; no synaptic vesicles; may have puncta adherentia between them. (4) Granule cell body: GABA immunonegative; oval or round soma of 5-8 $\mu \mathrm{m}$ diameter; little cytoplasm; densely packed.

The length of the sectioned plasma membrane of granule cells was measured using a digitizing tablet and the MACSTEREOLOGY computer program (Ranforly MicroSystems, UK).

The small immunometal particles were grouped in three categories and counted. If a gold particle was not further than $10 \mathrm{~nm}$ (approximately $0.5 \mathrm{~mm}$ on the micrographs; the "effective plasma membrane width") from the membrane we considered it to be associated with the plasma membrane. If it was further away we considered it to represent background, nonspecific distribution of immunometal particles. $A 11$ of these nonspecific particles were counted and the density per $\mathrm{nm}^{2}$ was determined. The area of section available for immunoreaction and occupied by the "effective width of granule cell plasmia menibrane" was calculated by multiplying the total measured length by $10 \mathrm{~nm}$. To obtain 

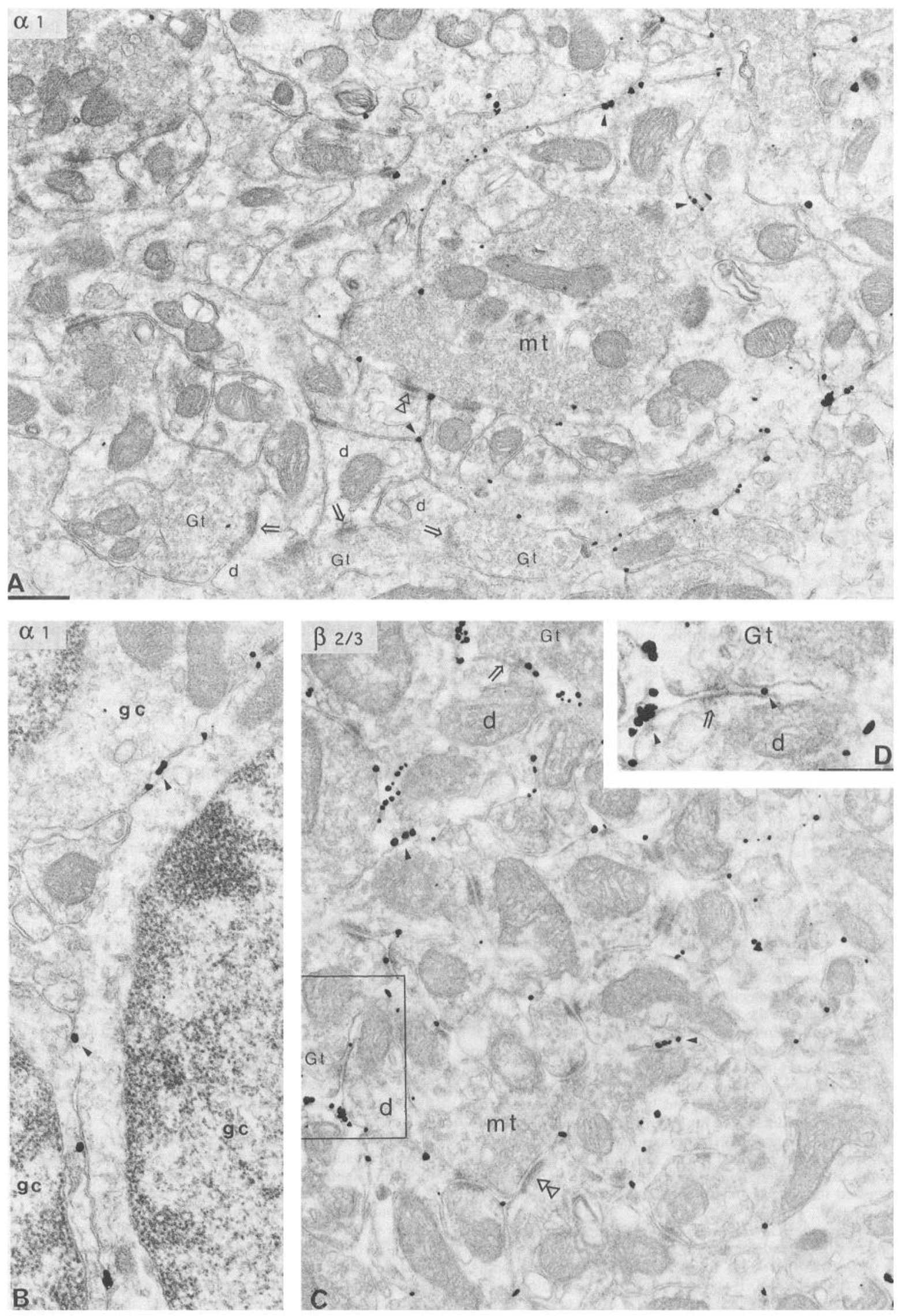

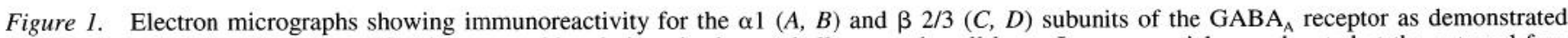
with a pre-embedding silver-intensified immunogold technique in the cerebellar granule cell layer. Immunoparticles are located at the external face 

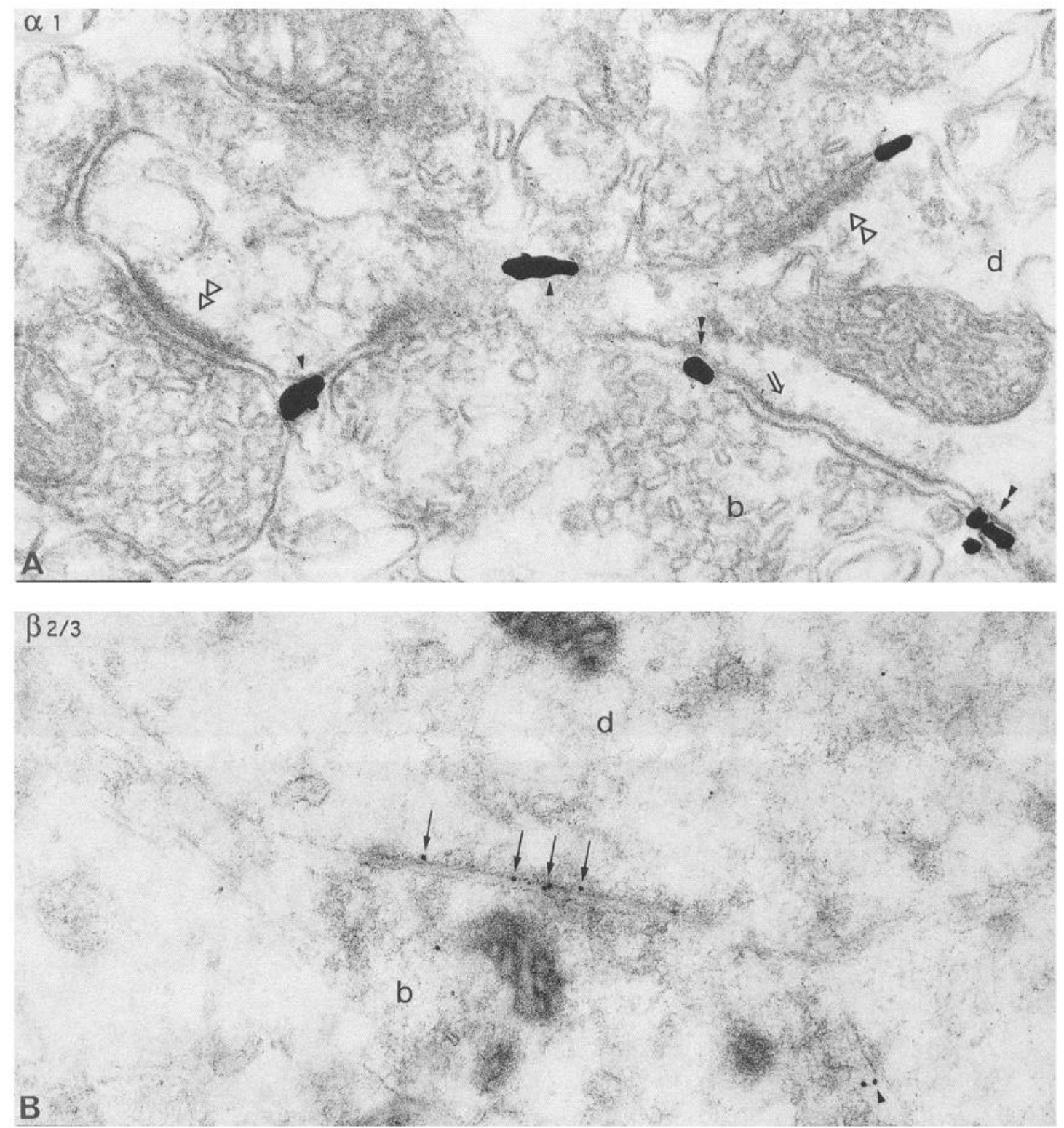

Figure 2. Immunoreactivity for the $\alpha 1(A)$ and $\beta 2 / 3(B)$ subunits in the molecular layer of cat cerebellum as demonstrated by either pre-embedding ( $A$, epoxy resin) or postembedding techniques ( $B$, freeze-substituted Lowicryl-embedded material). $A$, Particles are not present in synapses (double triangles), including the type 2 synapse (e.g., open arrow) between a presumed stellate cell terminal $(b)$ and an interneuron dendrite $(d)$. Immunoparticles are often located at the edge of type 2 synapses (double arrowheads) as well as at the extrasynaptic membrane (arrowheads). B, The postembedding reaction produces a row of silver-intensified gold particles (arrows) on the postsynaptic plasma membrane at a synaptic junction established by a bouton $(b)$ with a Purkinje cell dendrite $(d)$. Some immunoparticles are also present at the extrasynaptic plasma membrane (arrowhead). Scale bars, $0.2 \mu \mathrm{m}$.

gold density corrected for "background reaction," the above density was reduced by the density of the nonspecifically distributed gold. At each GABAergic synapse we measured the length of synaptic junction and counted the number of gold particles to calculate the synaptic immunoparticle density. We defined the width of the "effective synaptic plasma membrane" as $10 \mathrm{~nm}$.

\section{Results}

\section{Antibodies}

Monoclonal antibody bd-24 was shown to react only with the $\alpha 1$ subunit (Ewert et al., 1990) which is abundantly expressed

$\leftarrow$

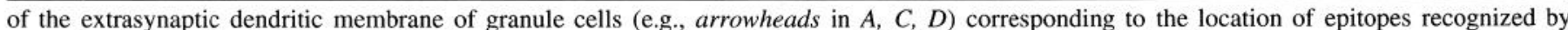

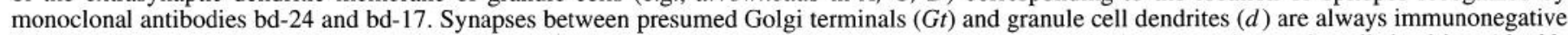

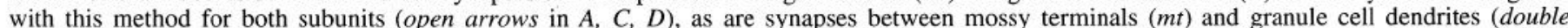

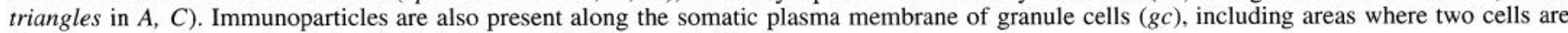
directly apposed (arrowheads in $B$ ). Scale bars: $A-C, 0.5 \mu \mathrm{m} ; D, 0.2 \mu \mathrm{m}$. 

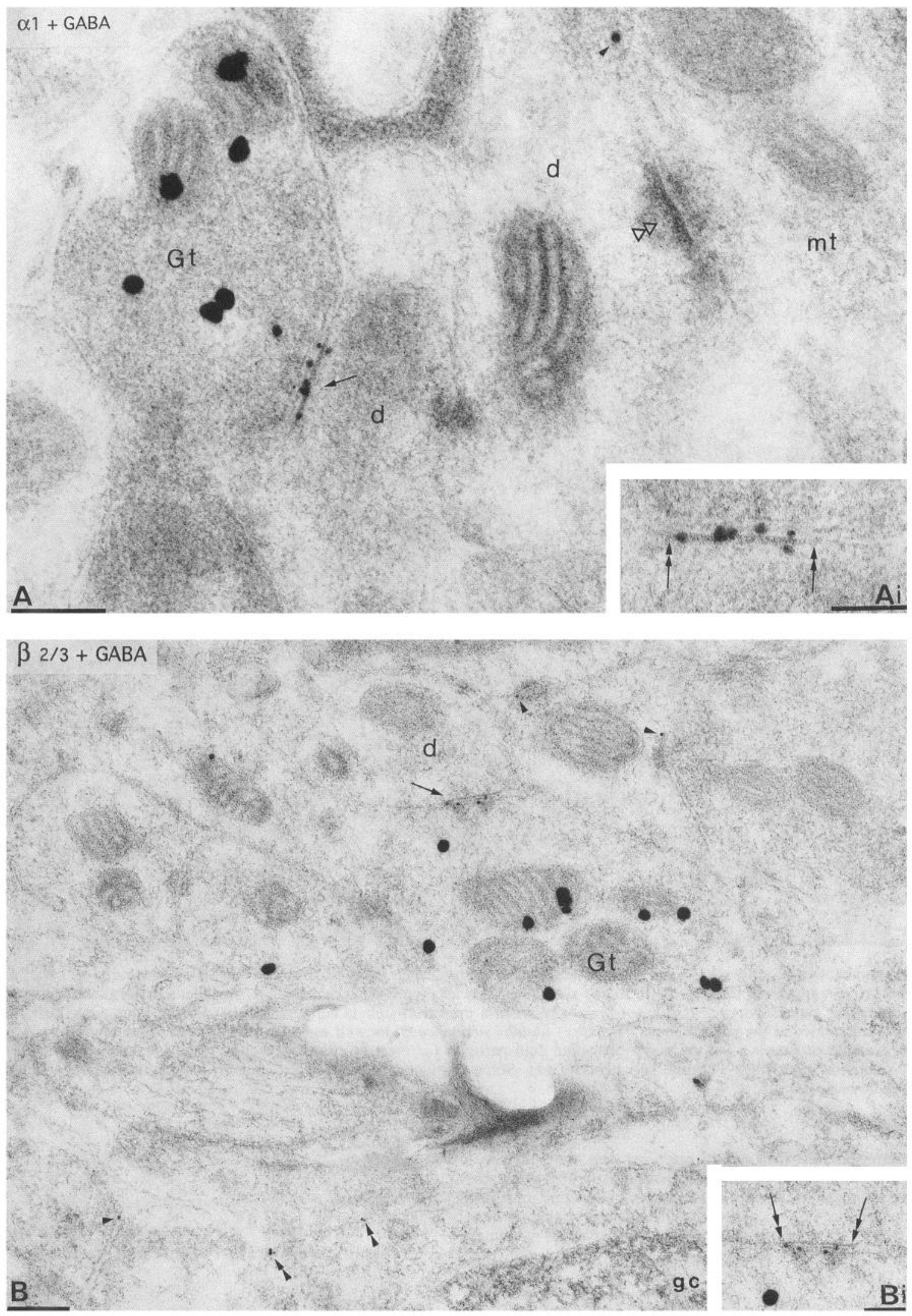

Figure 3. Electron micrographs of freeze-substituted, Lowicryl-embedded ultrathin sections demonstrating immunoreactivity for the $\alpha 1$ (A, Ai) or $\beta 2 / 3(B, B i)$ subunits of $\mathrm{GABA}_{\mathrm{A}}$ receptor (small particles, silver-intensified $1 \mathrm{~nm}$ gold) and for GABA (large particles, silver-intensified $15 \mathrm{~nm}$ gold). The enrichment of large particles shows GABA immunoreactivity of Golgi cell terminals (Gt). The synaptic junctions (arrow) are covered by small particles demonstrating enrichment of receptor immunoreactivity. Note the presence of receptor immunoparticles on the somatic ( $B$, double arrowheads) and extrasynaptic dendritic membrane (arrowheads) of granule cells $(\mathrm{gc})$ and the immunonegative synapse (double triangles) estab- 
by granule cells. Antibody bd-17 reacts with both the $\beta 2$ and $\beta 3$ subunits. Since granule cells express mRNA for both subunits (Laurie et al., 1992; Persohn et al., 1992), immunoreactivity is referred to as representing $\beta 2 / 3$ subunits. These subunits are highly homologous and it has not been possible to develop immunohistochemically usable antibodies that would differentiate between them.

\section{Pre-embedding immunogold localization of $G A B A_{A}$ receptors}

The use of the immunogold method confirmed some of the results obtained earlier with an immunoperoxidase method (De Blas et al., 1988; Meinecke et al., 1989; Somogyi et al., 1989). However, the absence of signal diffusion in the immunogold method makes the localization more accurate. Immunoparticles were restricted to the extracellular face of the somatic and dendritic membranes (Figs. $1 A-C, 2 A$ ) for both antibodies. The size of the particles is about the same as the width of the extracellular space, thus a particle touches both apposed plasma membranes. Therefore, the location of the epitope can be allocated to the process of a particular cell type when both apposed membranes belong to the same population, for example, granule cell dendrites. The putative epitope recognized by antibody bd- 24 was predicted to be in the N-terminal part of the polypeptide (Ewert et al., 1990), which is at the extracellular face of the plasma membrane. Thus the immunogold localization of the epitope is in agreement with the predicted transmembrane conformation of the polypeptide and also demonstrates that antibody bd-17, for which the epitope is unknown, also recognizes an extracellular epitope.

Granule cells showed the strongest immunoreactivity for the studied subunits of $\mathrm{GABA}_{\mathrm{A}}$ receptor in the cerebellum with immunoparticles located along the extrasynaptic dendritic membrane (Fig. 1A,C). Immunoreactivity was also present at the somatic membrane including areas where two somata were directly apposed (Fig. $1 B$ ), providing evidence that the receptor is in the granule cell membrane. Immunoreactivity was never observed in the asymmetrical synaptic junctions between the glutamatergic mossy fiber terminals and granule cell dendrites (Fig. 1A,C). Surprisingly, using the pre-embedding immunogold method, immunoparticles were also absent from the synaptic junctions established by Golgi cell terminals with granule cell dendrites (Fig. $1 A, C)$. An absence of immunoparticles was also observed in the symmetrical synapses between stellate or basket cell terminals and dendrites in the molecular layer (e.g., Fig. $2 A$ ). The lack of immunoreactivity for the $\mathrm{GABA}_{\mathrm{A}}$ receptor in the anatomically defined GABAergic synaptic junctions could be genuine or due to technical limitations, such as the inability of the immunoreagents to penetrate into the synaptic cleft, or the cleft material masking the epitopes. To decide between these possibilities, postembedding reactions were carried out on Lowicryl-embedded tissue.

\section{Postembedding immunogold localization of $G A B A_{A}$ receptors}

Using the postembedding method, electron microscopic ultrathin sections are floated onto antibody solutions, exposing directly the entire cut length of the membrane to the antibody, including the synaptic junctional membranes. No immunocytochemical la- beling could be obtained in epoxy resin-embedded tissue. Therefore, slam-frozen, freeze-substituted, Lowicryl-embedded material was used that has been useful for the high-resolution localization of glutamate receptors (Baude et al., 1993; Nusser et al., 1994). However, fine structural details in this material are less well defined than in osmium-treated, epoxy resin embedded tissue. Thus, in order to identify cellular profiles, and in particular Golgi cell terminals, GABA or synapsin immunolabeling were carried out on either the same (Figs. $3 A, B ; 4 A, B$ ) or serial (Fig. $4 C$ ) sections to those which were reacted for the $\mathrm{GABA}_{\mathrm{A}}$ receptor. Using double immunostaining experiments on the same ultrathin sections, large particles (silver-intensified $15 \mathrm{~nm}$ gold) indicate the immunoreactivity for GABA, whereas small particles (silver-intensified $1 \mathrm{~nm}$ gold) represent the immunoreactivity for the $\mathrm{GABA}_{\mathrm{A}}$ receptor subunits (Figs. $3 A, B ; 4 A, B$ ). Synaptic junctions were identified on the basis of the rigid apposition of the membranes of Golgi terminals and granule cell dendrites (Figs. 3, 4), the usually narrow but distinct postsynaptic membrane specialization (Figs. 3, 4), and, when present, the presynaptic dense material (Figs. $3 B, 4 A, C$ ).

In contrast to the result of the pre-embedding reactions, an enrichment of immunoparticles was detected for both the $\alpha 1$ and $\beta 2 / 3$ subunits in the synaptic junctions established by the GABAergic Golgi cell terminals and granule cell dendrites in Lowicryl-embedded tissue (Figs. 3, 4). The overwhelming majority of Golgi synapses were strongly immunopositive for the $\beta 2 / 3$ subunits (Figs. $3 B, 5$ ). Most of these synapses were also labeled with immunoparticles for the $\alpha 1$ subunit (Figs. 3A, 4A-C, 5), but sometimes an absence of the $\alpha 1$ subunit immunorcactivity was also observed (Figs. 4B, 5). Immunoparticles for the GA$B A_{\Lambda}$ receptor were located along the postsynaptic specialization in the main body of Golgi synapses (Figs. 3, 4), frequently in one or more clusters (Fig. $4 B$ ).

A similar result was obtained in the molecular layer. Synapses between terminals and Purkinje cell or interneuron dendrites showed strong immunoreactivity for the $\mathrm{GABA}_{\mathrm{A}}$ receptor using the postembedding method (Fig. 2B).

Postembedding immunogold reactions have also confirmed the extrasynaptic location of the immunoreactivity for the $\alpha 1$ and $\beta 2 / 3$ subunits on the somatic and dendritic membrane of granule cells (Figs. 3, 4). Immunoparticles for the $\beta 2 / 3$ subunits (Fig. $3 B$ ) were more frequent at the extrasynaptic dendritic membrane than for the $\alpha 1$ subunit (Figs. $3 A, 4 A-C$ ). The synapses between mossy fiber terminals and granule cell dendrites were always immunonegative for these $G A B A_{A}$ receptor subunits.

Relative immunoparticle densities on different compartments of the surface of granule cells

The immunogold reaction under postembedding conditions provided an opportunity to carry out a quantitative evaluation of immunoreactivity. Immunoparticle densities were calculated on different parts of the surface of cerebellar granule cells. Data were obtained from four different blocks $(4 / 8,3 / 8,1 \mathrm{a} / 10,1 \mathrm{~b} /$ 10) of two animals (cats $21 / 4$ and 1/6). Immunoreactions on different specimens and on separate occasions resulted in somewhat different overall density of particles. Therefore, relative 

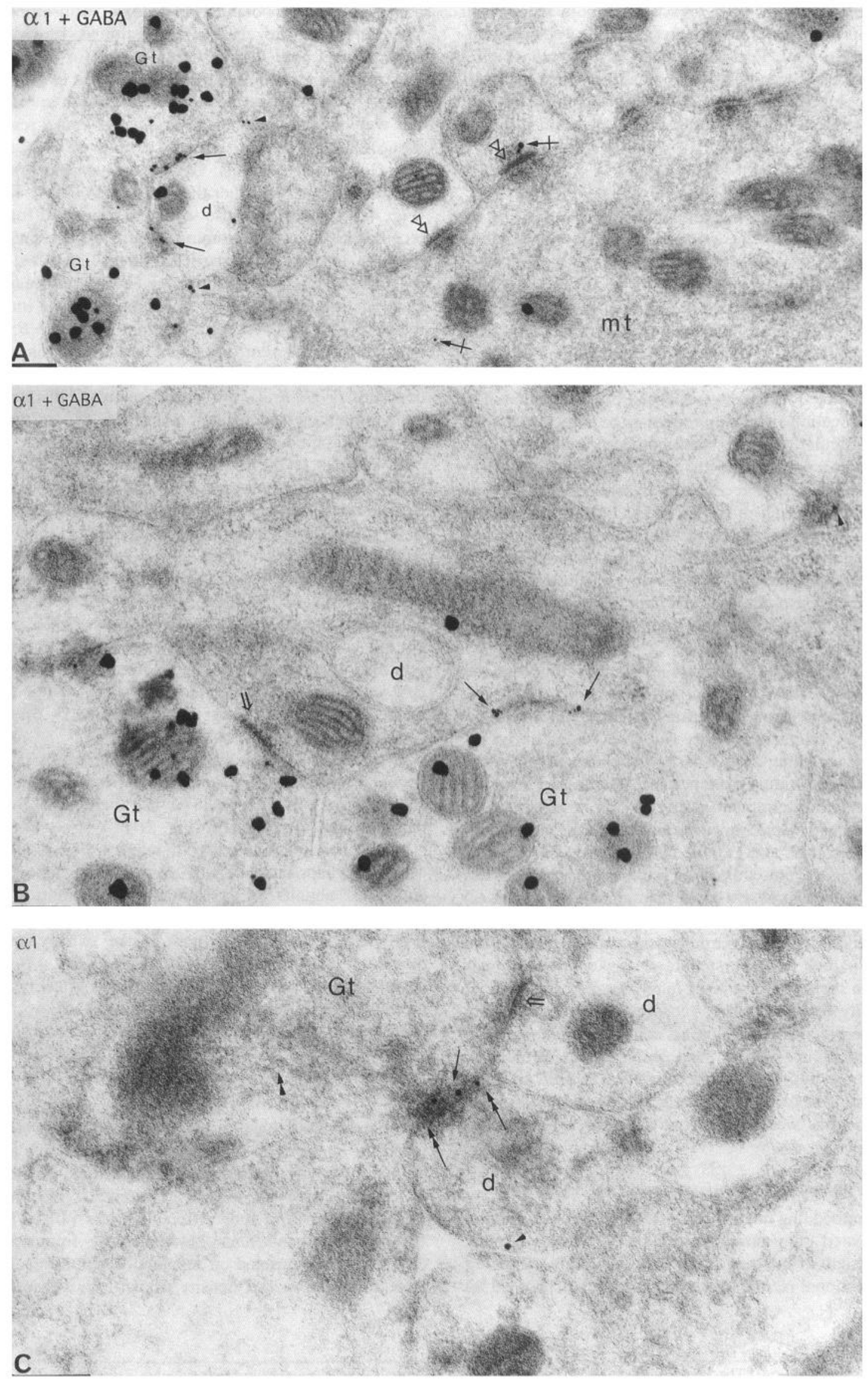
immunoparticle densities on somatic, extrasynaptic dendritic, and synaptic membranes were calculated by comparing densities obtained from the same ultrathin sections. The relative immunoparticle density for the $\beta 2 / 3$ subunits in the synapses established by Golgi cell terminals was 54.68 (10.38) [mean (SD)] times higher than in the extrasynaptic dendritic membrane (Table $1)$. For the $\alpha 1$ subunit, synaptic immunoparticle density was 127.24 (39.59) times higher than in the extrasynaptic dendritic membrane. The above result indicates a relative density approximately twice as high for the $\alpha 1$ subunit in the Golgi synapses as for the $\beta 2 / 3$ subunits (Table 1 ). The length of the measured extrasynaptic dendritic membranes was 155.25 (52.18) times longer than the length of Golgi synaptic membranes in the pictures, but dendrites were measured only in the glomeruli. Immunoparticle densities on the extrasynaptic dendritic membrane were $1.80(0.11)$ and $3.28(1.02)$ times higher for the $\alpha 1$ and $\beta 2 / 3$ subunits, respectively, than on the somatic membrane (Table 1). The ratios of immunoparticle density on the four separately examined compartments of the surface of granule cells, namely, the membrane postsynaptic to the mossy fiber terminals (MS), membrane of granule cell body (BG), extrasynaptic dendritic membrane of granule cell (DG), and postsynaptic membrane to the Golgi cell terminals (GS), were approximately MS: BG:DG:GS - 0:1:2:230 and MS:BG:DG:GS $=0: 1: 3.3: 180$ for the $\alpha 1$ and $\beta 2 / 3$ subunits, respectively.

\section{Are Golgi cell synapses homogeneous according to their $\alpha 1$ and $\beta 2 / 3$ subunits' immunoreactivity?}

Measuring every Golgi cell synapse on our micrographs, synaptic immunoparticle density for the $\beta 2 / 3$ subunits was calculated as being $18.37(9.12)$ and $19.55(9.50)$ particle/ $\mu \mathrm{m} \mathrm{mem-}$ brane in cats $12 / 4$ and $1 / 6$, respectively. This corresponds to 3.2 immunoparticles per Golgi cell synapse [average length, 0.17 $(0.02) \mu \mathrm{m}]$. The frequency distribution of synapses immunoreactive for the $\beta 2 / 3$ subunits was normal in both animals (Fig. $5 B$ ), indicating the existence of one population of Golgi synapses (Fig. 5B).

Immunoparticle density for the $\alpha 1$ subunit was 16.81 (10.85) and $18.28(9.47)$ particle/ $\mu \mathrm{m}$ membrane in cats $12 / 4$ and $1 / 6$, respectively, when every Golgi cell synapse was included (Fig. $5 A$ ). However, the frequency distributions of the $\alpha 1$ subunit immunoreactive synapses, provided by GABA-positive terminals, significantly differed from normal (Fig. 5A), and a high proportion of immunonegative synapses was observed. This suggests the possibility of two populations of GABAergic synapses in cerebellar glomeruli with regard to $\alpha 1$ subunit concentration. One of the two populations may have a lower density or no $\alpha 1$ subunit (see Fig. 4 for immunonegative synapses). When synapses having more than one immunoparticle for the $\alpha 1$ subunit were tested for heterogeneity the population was not significantly different from normal (Table 1), indicating that they formed one population. Therefore, in the calculations of relative immunoreactivity signals between synaptic versus nonsynaptic plasma membranes, we used for comparison the synapse population showing a higher density of immunoparticles [Table 1, mean $22.26(6.11)$ and 21.92 (6.49) particle/ $\mu \mathrm{m}$ membrane in cats $12 / 4$ and $1 / 6$, respectively].

\section{Discussion}

\section{Synaptic enrichment of $G A B A_{A}$ receptors}

Postsynaptic neurotransmitter receptors in the brain are thought to be located at high concentration in the junctional plasma membrane opposite to the transmitter release site. The results of this study demonstrate that immunoreactivity for the ionotropic $\mathrm{GABA}_{\mathrm{A}}$ receptor is highly concentrated in the main body of the GABAergic synaptic junction and there is a sharp decrease in labeling density at the edge of the synaptic specialization. Assuming that the antibodies used in this study recognize reccptors at different locations in the membrane with equal probability, the differences in labeling density probably reflect differences in receptor/channel densities.

Prior to the present high-resolution localization of receptors, the best evidence for the close association of transmitter release and receptor location has been provided by the fast onset and rise time of IPSCs evoked by spontaneously released transmitter in preparations that maintain the organization of brain tissue (Edwards et al., 1990; Konnerth et al., 1990; Otis and Mody, 1992; Llano and Gerschenfeld, 1993; De Koninck and Mody, 1994; Puia et al., 1994; Soltesz and Mody, 1994). At synaptic sites, $10-60 \mathrm{GABA}_{\mathrm{A}}$ receptor channels have been suggested to be activated by a single packet of transmitter (Edwards et al., 1990; De Koninck and Mody, 1994; Soltesz and Mody, 1994), suggesting a synaptic enrichment of the receptors. However, outside-out patch-clamp recording of single receptor channels obtained from somatic and dendritic membrane of different neurons demonstrated $\mathrm{GABA}_{\Lambda}$ receptors at extrasynaptic sites having pharmacological and kinetic parameters similar to those predicted for synaptic receptors (Cull-Candy and Ogden, 1985; Edwards et al., 1990; Sakmann, 1992; Llano and Gerschenfeld, 1993; Kaneda et al., 1994; Macdonald and Olsen, 1994; Puia et al., 1994). The extrasynaptic presence of receptors has been confirmed by immunocytochemical localization of $\mathrm{GABA}_{\mathrm{A}}$ receptor protein at extrasynaptic membranes using immunoperoxidase methods (Richards et al., 1987; De Blas et al., 1988; Meinecke et al., 1989; Somogyi, 1989; Somogyi et al., 1989; Yazulla et al., 1989; Soltesz et al., 1990; Waldvogel et al., 1990; Greferath et al., 1993; Spreafico et al., 1993a). The latter studies could not show an enrichment of receptor in the synaptic junction due to the limitations of the technique.

Further uncertainty into the precise location of receptors was introduced by the unexpected exclusion of the metabotropic glutamate receptor from the main body of the synaptic junction. Using a high-resolution particulate immunomarker it was found that the metabotropic receptor was concentrated at the edge of the synaptic specialization, still within easy reach of transmitter, but nevertheless largely outside the anatomically defined syn-

$\leftarrow$

Figure 4. Immunoreactivity for the $\alpha 1$ subunit of the $\mathrm{GABA}_{\mathrm{A}}$ receptor (small particles, silver enhanced $1 \mathrm{~nm}$ gold) and for GABA (Iarge particles,

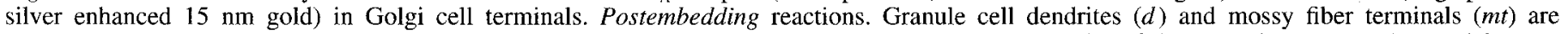

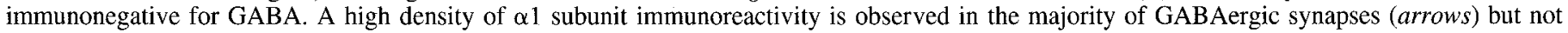

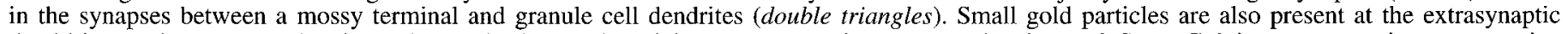

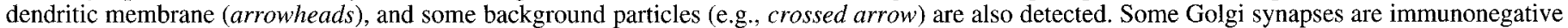

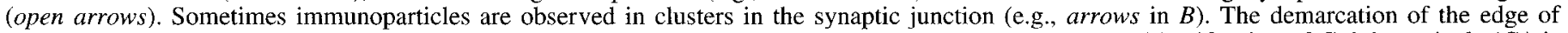

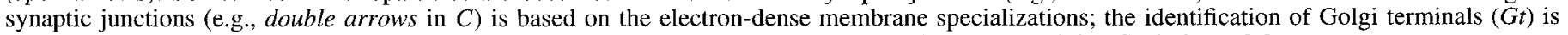
based on the presence of synaptic vesicles (e.g., double arrowhead in $C$ ) and GABA immunoreactivity. Scale bars, $0.2 \mu m$. 


\section{Synaptic GABAA receptor $\alpha 1$ subunit}

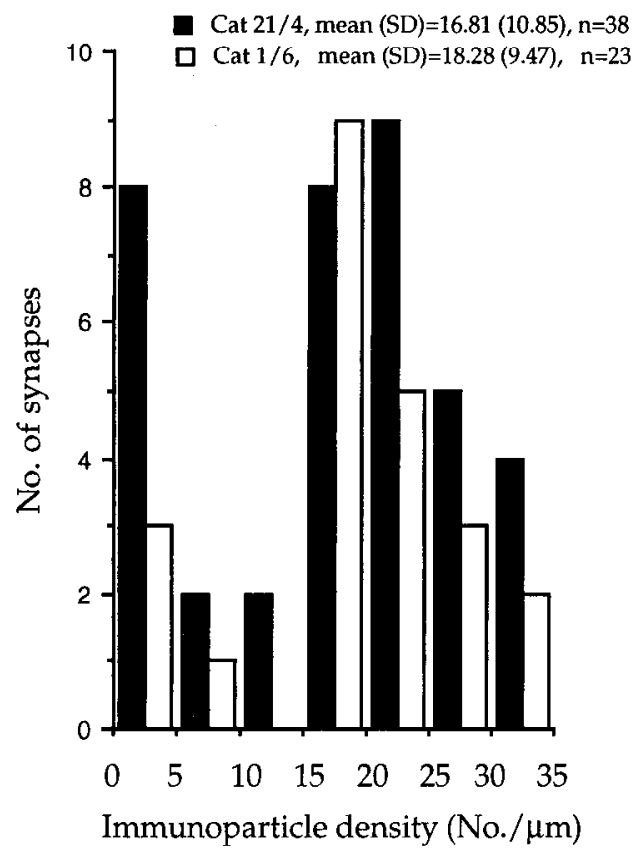

Synaptic GABAA receptor $\beta 2 / 3$ subunits

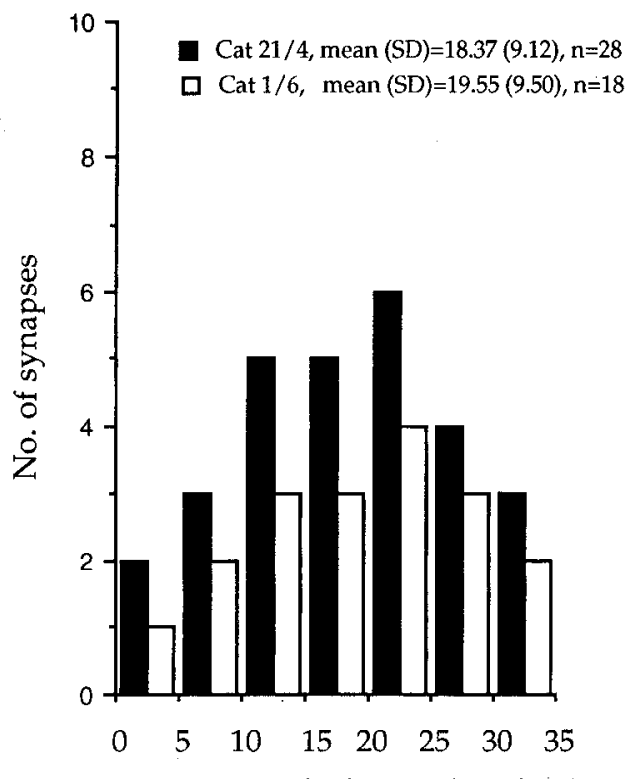

Immunoparticle density (No. $/ \mu \mathrm{m})$

Figure 5. Quantitative distribution of synapses established by Golgi cell terminals and granule cell dendrites according to their $\alpha 1(A)$ and $\beta 2 / 3(B)$ subunits' immunoreactivity. $A$, The distribution of Golgi synapses with regard to $\alpha 1$ subunit immunoreactivity is different from normal distribution $\left(\chi^{2}\right.$ test, $\left.\chi^{2}=17.46, p<0.002\right)$, indicating two populations of synapses. The distribution in the two animals is not different (Mann-Whitney test, $Z=-0.11, p=0.91$ ). $B$, The frequency distribution of the $\beta 2 / 3$ subunits immunoreactive Golgi synapses is normal in both animals $\left(\chi^{2}\right.$ test: cat $21 / 4, \chi^{2}=0.115, p=0.862$; cat $1 / 6, \chi^{2}$ $=0.096, p=0.997)$, indicating one population of Golgi synapses for $\beta 2 / 3$ subunits immunoreactivity. aptic junction (Baude et al., 1993; Nusser et al., 1994). The present finding of the ionotropic $\mathrm{GABA}_{\mathrm{A}}$ receptor concentrated in the main body of the GABAergic synapses demonstrates that the perisynaptic location may be peculiar for the G-protein-coupled receptors. Indeed another fast, ionotropic amino acid receptor, the $\alpha$-amino-3-hydroxy-5-methylisoxazole-4-propionatetype glutamate receptor, is also highly concentrated in the postsynaptic membrane specialization, as revealed by the postembedding immunogold method (Nusser et al., 1994).

Immunoparticles for the $\mathrm{GABA}_{\mathrm{A}}$ receptor were often distributed in one or more groups along the main body of the postsynaptic membrane, indicating a possible clustering of receptors. There is a sharp decrease in immunoparticle density at the edge of the synaptic specialization for both the $\alpha$ and the $\beta$ subunits of the $\mathrm{GABA}_{\mathrm{A}}$ receptor. Using confocal immunofluorescent mapping, both $\mathrm{GABA}_{\mathrm{A}}$ and glycine receptors have been found to be concentrated in patches having sharp borders on the surface of central neurons (Becker et al., 1991; Triller et al., 1991; Nicola et al., 1992; Bohlhalter et al., 1994). The concentrated placement of receptors with a sharp decrease in channel density at the edge of the synaptic specialization ensures that diffusion of transmitter from the release site to the synaptically activated receptor channels does not prolong the fast activation of postsynaptic response. Another factor that may contribute to the abrupt decrease of receptor protein at the edge of the anatomically defined synaptic junction is that the edge of the synapse may be occupied preferentially by other membrane proteins such as G-protein-coupled receptors and the voltage-gated ion channels that they modulate (Baude et al., 1993; Nusser et al., 1994).

\section{Compartmentalized distribution of the $\alpha 1$ and $\beta 2 / 3$ subunits on the surface of cerebellar granule cells}

In addition to the high concentration of the $\alpha 1$ and $\beta 2 / 3$ subunits of the $\mathrm{GABA}_{\mathrm{A}}$ receptor in the GABAergic synaptic junction, consistent levels of nonsynaptic labeling on the same cells have also been found. In contrast, no $\mathrm{GABA}_{\mathrm{A}}$ receptors could be detected, with our antibodies and at the sensitivity level of our method, in mossy fiber synapses, demonstrating the ability of the cell to exclude this protein from glutamatergic synapses. The density of receptors also seems to decrease in the nonsynaptic plasma membrane the further the membrane is from the GABA release site. Thus, the membrane of the granule cell body, which does not receive any synaptic contact, showed significantly lower immunolabeling than the nonsynaptic dendritic membrane in the glomeruli. We did not try to measure separately proximal versus distal dendritic membrane due to the convoluted course of granule cell dendrites, which in any case are very short compared to the dendrites of other central neurons. In the absence of GABAergic innervation, cultured granule cells show a relatively even distribution of $\mathrm{GABA}_{\mathrm{A}}$ receptors on their dendritic and somatic plasma membranes, although a high concentration of labeling has been reported in spots (Hansen et al., 1991). Furthermore, it has been shown that GABA and the GABA receptor agonist 4,5,6,7-tetrahydroisoxazolo [5,4-c]pyridin-3-ol enhance the morphological development of the cells (Hansen et al., 1984). They also promote expression of low-affinity GABA $_{A}$ receptors.(Meier et al., 1984; Belhage et al., 1986; Kim et al., 1993 ) and the density of immunocytochemically detected GA$\mathrm{BA}_{\mathrm{A}}$ receptors (Hansen et al., 1991) in cultured cerebellar granule cells. It is possible that in situ in the brain, the GABAergic nerve terminal, similar to the cholinergic endplate in the neuromuscular junction (Fambrough, 1979; Laufer and Changeux, 
Table 1. Absolute and relative immunoparticle densities for the $\alpha 1$ and $\beta 2 / 3$ subunits of the $\mathrm{GABA}_{\mathrm{A}}$ receptor on the somatic, extrasynaptic dendritic, and GABAergic synaptic membranes of granule cells

\begin{tabular}{|c|c|c|c|c|c|c|c|c|}
\hline \multirow[b]{2}{*}{ Subunit } & \multirow[b]{2}{*}{ Animals } & \multirow[b]{2}{*}{ Blocks } & \multicolumn{3}{|c|}{ Immunoparticle density (particle/ $\mu \mathrm{m}$ membrane) } & \multirow[b]{2}{*}{$\begin{array}{l}\text { Syn./dend. } \\
\text { ratio }\end{array}$} & \multirow[b]{2}{*}{$\begin{array}{l}\text { Syn./som. } \\
\text { ratio }\end{array}$} & \multirow[b]{2}{*}{$\begin{array}{l}\text { Dend./som. } \\
\text { ratio }\end{array}$} \\
\hline & & & Somatic & $\begin{array}{l}\text { Dendritic mean } \\
\text { (SD) }\left[n^{+}\right]\end{array}$ & $\begin{array}{l}\text { Synaptic mean } \\
\text { (SD) }[n]\end{array}$ & & & \\
\hline \multirow[t]{4}{*}{$\alpha 1$} & $21 / 4$ & $4 / 8$ & 0.108 & $0.209(0.071)[11]$ & $23.59(6.17)[13]$ & 114.59 & 218.43 & 1.93 \\
\hline & & $3 / 8$ & 0.103 & $0.190(0.080)[10]$ & $21.35(5.89)[15]$ & 112.36 & 207.28 & 1.84 \\
\hline & $1 / 6$ & $1 \mathrm{a} / 10$ & 0.055 & $0.096(0.034)[5]$ & $17.80(2.59)[6]$ & 185.41 & 323.64 & 1.74 \\
\hline & & $1 b / 10$ & 0.144 & $0.241(0.128)[10]$ & $23.29(7.10)[13]$ & 96.63 & 161.74 & 1.67 \\
\hline Mean (SD) & & & $0.103(0.036)^{*}$ & $0.184(0.062)^{*}$ & $21.51(2.66)$ & $127.24(39.59)$ & $227.77(68.45)$ & $1.80(0.11)$ \\
\hline \multirow[t]{4}{*}{$\beta 2 / 3$} & $21 / 4$ & $4 / 8$ & 0.108 & $0.368(0.065)[5]$ & $20.75(9.56)[10]$ & 56.38 & 192.12 & 3.40 \\
\hline & & $3 / 8$ & 0.181 & $0.327(0.208)[10]$ & $17.04(8.86)[18]$ & 52.11 & 94.14 & 1.80 \\
\hline & $1 / 6$ & $\mathrm{Ia} / 10$ & 0.086 & $0.3560 .053[5]$ & 24.08 (3.56) [7] & 67.64 & 280 & 4.12 \\
\hline & & $1 b / 10$ & 0.103 & $0.3910 .175[5]$ & $16.66(11.06)[11]$ & 42.60 & 161.74 & 3.79 \\
\hline Mean (SD) & & & $0.120(0.042)^{* *}$ & $0.361(0.026)^{* * *}$ & $19.63(3.49)$ & $\mathbf{5 4 . 6 8}(10.38)$ & $182(77.1)$ & $3.28(1.02)$ \\
\hline
\end{tabular}

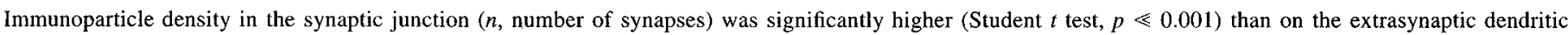

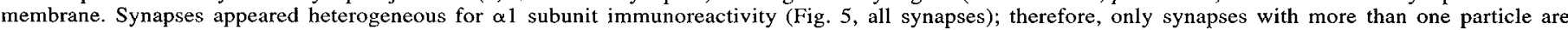

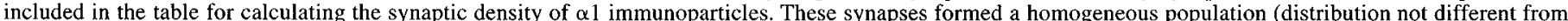

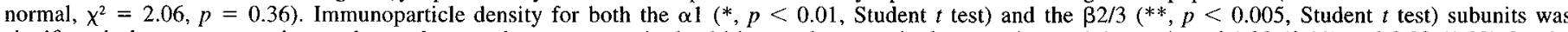

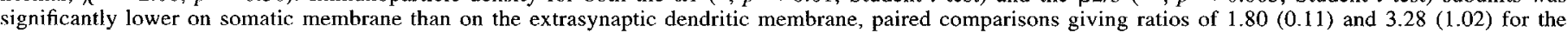

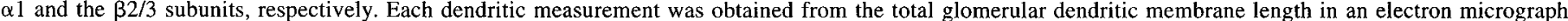

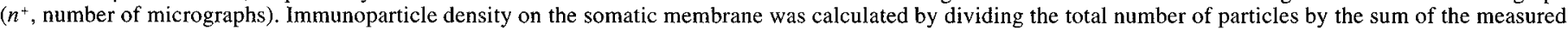
somatic membrane length $[69(34) \mu \mathrm{m} / \mathrm{block}]$ from several micrographs obtained from each block.

1989), is responsible for increasing and maintaining a high receptor concentration close to the release site in the GABAergic synaptic junction.

It is not yet known how the measured immunoparticle density is related to receptor channel density. If a saturation of immunocytochemical signal occurs at high channel density, for example in the synaptic membrane, then the approximately 125 ( $\alpha 1$ subunit, higher density synapse population) and $55(\beta 2 / 3$ subunits, all synapses) times enrichment of signal in the synaptic junction relative to nonsynaptic dendritic membrane would be an underestimate of real channel density differences. The relative particle densitics at sites labeled at low level are probably more representative of channel density differences. In any case, the absolute number of extrasynaptic receptors could be higher than all the receptors in synaptic junctions. Only a small fraction of the granule cell membrane is covered by GABAergic synapses. Taking into account the measured synaptic and nonsynaptic dendritic plasma membrane ratio in the glomeruli (although not all extrasynaptic reactivity could be measured and the value is an underestimate), it can be calculated that at least three and 1.25 times more $\beta 2 / 3$ and $\alpha 1$ subunits exist, respectively, at extrasynaptic glomerular sites than at synaptic sites. These values are further increased by adding the nonglomerular dendritic and somatic extrasynaptic receptors.

The possible functional role of extrasynaptic receptors at sites remote from GABAergic synapses has been discussed earlier (Somogyi et al., 1989). A recent electrophysiological study on cerebellar granule cells demonstrated that $\mathrm{G} \Lambda \mathrm{B} \Lambda$-evoked currents in outside-out nucleated patches, presumably corresponding to the somatic membrane and therefore containing only extrasynaptic receptors, and spontaneous IPSCs, evoked synaptically, had similar kinetic and pharmacological properties (Puia et al., 1994). On the other hand, GABA exogenously applied to granule cells in the dentate gyrus activates $\mathrm{GABA}_{\mathrm{A}}$ receptor channels with kinetics dissimilar to those at the synapse (De Koninck and Mody, 1994). Thus, it is still uncertain whether extrasynaptic receptors are functionally similar to synaptic receptors.

\section{Two populations of Golgi synapses for $\alpha 1$ subunit immunoreactivity}

Cerebellar granule cells express mRNA for the $\alpha 1, \alpha 4, \alpha 5, \alpha 6$, $\beta 1, \beta 2, \beta 3, \gamma 2$, and $\delta$ subunits of the $\mathrm{GABA}_{\mathrm{A}}$ receptor, as detected by in situ hybridization (Laurie et al., 1992; Persohn et al., 1992). Immunocytochemical studies have demonstrated the $\alpha 1, \alpha 3, \alpha 6, \beta 2 / 3, \gamma 2$, and $\delta$ subunits in the granule cell layer and the enrichment of immunoreactivity in the glomeruli indicates that the receptor may be located in the dendritic membrane (Richards et al., 1987; De Blas et al, 1988; Meinecke et al., 1989; Somogyi et al., 1989; Benke et al., 1991b,c; Zimprich et al., 1991; Baude et al., 1992; Thompson et al., 1992; Turner et al., 1994). Immunoprecipitation studies show that not all the subunits are combined into the same channel assembly (Duggan and Stephenson, 1990; Benke et al., 1991a; Duggan et al., 1991; Luddens el al., 1991; McKernan el al., 1991; Zezula el al., 1991; Endo and Olsen, 1993; Mertens et al., 1993; Pollard et al., 1993; Khan et al., 1994; Quirk et al., 1994; Togel et al., 1994). Furthermore, the kinetic properties of channels vary according to subunit composition (Pritchett et al., 1989; Sigel et al., 1990; Verdoorn et al., 1990; Angelotti and Macdonald, 1993; Mathews et al., 1994). Since individual granule cells receive GABA in a largely homogeneous population of synapses on their distal dendrites mainly from Golgi cells, the multiple channel types could all be located in the same synapses. This is supported by recent results showing that granule cells respond to synaptically released GABA with at least two different current components which are differentially modulated by diazepam, indicating the existence of different receptor channels (Puia et al., 1994).

Quantification of Golgi cell synapses for $\alpha 1$ subunit immunoreactivity indicates the possible presence of two populations of synapses with different levels of this subunit, but one population for the $\beta$ subunits. All $\mathrm{GABA}_{\mathrm{A}}$ receptor channels in vivo 
are thought to contain $\beta$ subunits (Schofield et al., 1987; Sigel et al., 1990; Verdoorn et al., 1990; Amin and Weiss, 1993; Angelotti and Macdonald, 1993). Granule cells express mRNA for the $\beta 2$ and $\beta 3$ subunits at high levels, but only moderate expression for the $\beta 1$ subunit has been detected using in situ hybridization (Laurie et al., 1992; Persolin et al., 1992). Indeed, the granule cell layer appears to be immunonegative for the $\beta 1$ subunit, demonstrating that either cerebellar granule cells do not express $\beta 1$ subunit protein or express it at a very low level ( $Z$. Nusser, W. Sieghart, and P. Somogyi, unpublished observations). Monoclonal antibody bd-17 used in our study recognizes epitopes on both $\beta 2$ and $\beta 3$ subunits (Ewert et al., 1990). Therefore, it is assumed that the overwhelming majority of $\mathrm{GABA}_{\mathrm{A}}$ receptor channels are recognized by antibody bd-17 on granule cells. Because only one population of Golgi synapse was found ac cording to $\beta 2 / 3$ subunit immunoreactivity, it is unlikely that the existence of two populations for the $\alpha 1$ subunit is a result of the presence of synapses with different numbers of GABA receptor channels. A more likely explanation is that those Golgi synapses having lower $\alpha 1$ subunit immunoreactivity may contain higher concentrations of receptor channels in which the $\alpha 1$ subunit is replaced by another $\alpha$ subunit, probably the $\alpha 6$ subunit, known to be present in granule cells at high levels (Baude et al., 1992; Laurie et al., 1992; Persohn et al., 1992; Thompson et al., 1992). Immunoreactivity for the $\alpha 6$ subunit has been shown in synapses between Golgi cell terminals and granule cell dendrites of rat (Baude et al., 1992). Unfortunately, our antibody recognizes epitopes on the $\alpha 6$ subunit of the rat but not on that of the cat (Baude et al., 1992) and, conversely, the antibody to the $\alpha 1$ subunit does not recognize this subunit in rat (Ewert et al., 1990). Therefore, we were unable to colocalize these two $\alpha$ subunits or to calculate relative densities on different compartments of the surface of granule cells in the same species.

In conclusion, it has been demonstrated that the postembedding immunogold method is suitable for the measurement of relative neurotransmitter receptor densities in different parts of the same cell and it should also be possible to compare different cell types. The expression of $\mathrm{GABA}_{\mathrm{A}}$ rcceptor and its availability to ligands on the cell surface changes rapidly in the brain upon the influence of sensory stimuli, environmental factors, neurodegenerative disorders, and exposure of the animal to drugs (Hendry et al., 1990; Morrow et al., 1992; Li et al., 1993; Mhatre et al., 1993; Mody, 1993; Montpied et al., 1993; Spreafico et al., 1993b). The present approach offers a sensitive and high-resolution method to define the cellular and subcellular sites for these changes with a resolution of about $20 \mathrm{~nm}$.

Note added to the proof: After the acceptance of this article it came to our attention that Caruncho and his colleagues (Caruncho et al., 1993; Caruncho and Costa, 1994) reported concentration of the $\alpha 1, \alpha 6, \beta 2 / 3, \gamma 2$ and $\delta$ subunits of the GABA receptor in patches on the somata of cultured cerebellar granule cells. The existence of synapses or the relationship of the receptor clusters to synapses on cultured granule cells in unknown.

\section{References}

Amin J, Weiss DS (1993) $\mathrm{GABA}_{\mathrm{A}}$ receptor needs 2 homologous domains of the $\beta$-subunit for activation by GABA but not by pentobarbital. Nature 366:565-569.

Angelotti TP, Macdonald RL (1993) Assembly of $\mathrm{GABA}_{\mathrm{A}}$ receptor subunits: $\alpha_{1} \beta_{1}$ and $\alpha_{1} \beta_{1} \gamma_{2 \sigma}$ subunits produce unique ion channels with dissimilar single-channel properties. J Neurosci 13:1429-1440.

Baude A, Sequier J-M, McKernan RM, Olivier KR, Somogyi P (1992)
Differential subcellular distribution of the $\alpha 6$ subunit versus the $\alpha 1$ and $\beta 2 / 3$ subunits of the GABA /benzodiazepine receptor complex in granule cells of the cerebellar cortex. Neuroscience 51:739-748.

Baude A. Nusser Z, Roberts JDB, Mulvihill E, McIlhinney RAJ, Somogyi P (1993) The metabotropic glutamate receptor (mGluR $1 \alpha$ ) is concentrated at perisynaptic membrane of neuronal subpopulations as detected by immunogold reaction. Neuron 11:771-787.

Becker C-M, Seitanidou T, Triller A (1991) Conservation of antigenic epitopes of the inhibitory glycine receptor in rodent and goldfish CNS. Mol Brain Res 11:327-333.

Belhage B, Meier E, Schousboe A (1986) GABA-agonists induce the formation of low affinity GABA-receptors on cultured cerebellar granule cells via preexisting high affinity GABA-receptors. Neurochem Res 11:599-606.

Benke D, Cicin-Sain A, Mertens S, Mohler H (1991a) Immunochemical identification of the $\alpha 1$ - and $\alpha 3$-subunits of the $\mathrm{GABA}_{\mathrm{A}}$-receptor in rat brain. J Recept Res 11:407-424.

Benke D, Mertens S, Trzeciak A, Gillessen D, Mohler H (1991b) GA$\mathrm{BA}_{\mathrm{A}}$ receptors display association of $\gamma 2$-subunit with $\alpha 1-$ and $\beta 2 / 3$ subunits. J Biol Chem 266:4478-4483.

Benke D, Mertens S, Trzcciak A, Gillessen D, Mohler H (1991c) Identification and immunohistochemical mapping of $\mathrm{GABA}_{\mathrm{A}}$ receptor subtypes containing the $\delta$-subunit in rat brain. FEBS Lett 283:145149.

Bohlhalter S, Mohler H, Fritschy J-M (1994) Inhibitory neurotransmission in rat spinal cord: co-localization of glycine- and $\mathrm{GABA}_{\mathrm{A}}$ receptors at GABAergic synaptic contacts demonstrated by triple immunofluorescence staining. Brain Res 642:59-69.

Caruncho HJ, Costa E (1994) Double-immunolabelling analysis of $\mathrm{GABA}_{\mathrm{A}}$ receptor subunits in label-fracture replicas of cultured rat cerebellar granule cells. Receptors Channels 2:143-153.

Caruncho HJ, Puia G, Slobodyansky E, Pinto P, da Silva PP, Costa E (1993) Freeze-fracture immunocytochemical study of the expression of native and recombinant $\mathrm{GABA}_{\mathrm{A}}$ receptors. Brain Res 603:234242 .

Cull-Candy SG, Ogden DC (1985) Ion channels activated by L-glutamate and GABA in cultured cerebellar neurons of the rat. Proc $R$ Soc Lond [Biol] 224:367-373.

De Blas AL, Vitorica J, Friedrich P (1988) Localization of the GABA receptor in the rat brain with a monoclonal antibody to the 57,000 $\mathrm{Mr}$ peptide of the $\mathrm{GABA}_{\mathrm{A}}$ receptor/benzodiazepine receptor/ $\mathrm{Cl}^{-}$ channel complex. J Neurosci 8:602-614.

De Koninck Y, Mody I (1994) Noise analysis of miniature IPSCs in adult rat brain slices: properties and modulation of synaptic GABA a receptor channels. J Neurophysiol 71:1318-1335.

Duggan MJ, Stephenson FA (1990) Biochemical evidence for the ex-

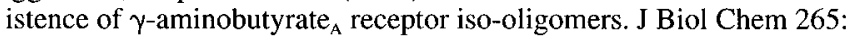
$3831-3835$.

Duggan MJ, Pollard S, Stephenson A (1991) Immunoaffinity purification of $\mathrm{GABA}_{\mathrm{A}}$ receptor $\alpha$-subunit iso-oligomers. J Biol Chem 266: 24778-24784.

Edwards FA, Konnerth A, Sakmann B (1990) Quantal analysis of inhibitory synaptic transmission in the dentate gyrus of rat hippocampal slices: a patch-clamp study. J Physiol (I ond) 430:213-249

Endo S, Olsen RW (1993) Antibodies specific for alpha-subunit subtypes of $\mathrm{GABA}_{\mathrm{A}}$ receptors reveal brain regional heterogeneity. J Neurochem 60:1388-1398.

Ewert M, Shivers BD, Luddens H, Mohler H, Seeburg PH (1990) Subunit selectivity and epitope characterization of mAbs directed against the GABA /benzodiazepine receptor. J Cell Biol 110:2043-2048.

Fambrough D (1979) Control of acetylcholine receptors in skeletal muscle. Physiol Rev 59:165-227.

Fujimoto T (1993) Calcium pump of the plasma membrane is localized in caveolae. J Cell Biol 120:1147-1157.

Gorcs TJ, Penke B, Boti Z, Katarova Z. Hamori J (1993) Immunohistochemical visualization of a metabotropic glutamate receptor. NeuroReport 4:283-286.

Greferath U, Muller F, Wassle H, Shivers B, Seeburg P (1993) Localization of $\mathrm{GABA}_{\mathrm{A}}$ receptors in the rat retina. Visual Neurosci 10 : $551-561$.

Hansen GH, Meier E, Schousboe A (1984) GABA influences the ultrastructure composition of cerebellar granule cells during development in culture. Int $\mathbf{J}$ Dev Neurosci 2:247-257.

Hansen GH, Belhage B, Schousboe A (1991) Effect of a GABA agonist on the expression and distribution of $\mathrm{GABA}_{\mathrm{A}}$ receptors in the 
plasma membrane of cultured cerebellar granule cells: an immunocytochemical study. Neurosci Lett 124:162-165.

Haring P, Stahli C, Schoch P, Takacs B, Staehelin T, Mohler H (1985) Monoclonal antibodies reveal structural homogeneity of $\gamma$-aminobutyric acid/benzodiazepine receptors in different brain areas. Proc Natl Acad Sci USA 82:4837-4841.

Hendry SHC, Fuchs J, De Blas AL, Jones EG (1990) Distribution and plasticity of immunocytochemically localized $\mathrm{GABA}_{\mathrm{A}}$ receptors in adult monkey visual cortex. J Neurosci 10:2438-2450.

Hodgson AJ, Penke B, Erdei A, Chubb IW, Somogyi P (1985) Antisera to $\gamma$-aminobutyric acid. I. Production and characterization using a new model system. J Histochem Cytochem 33:229-239.

Kaneda M, Farrant M, Cull-Candy SG (1994) GABA- and glycineactivated currents in granule cells of the rat cerebellum. J Physiol Abstr 476.P:68P.

Khan ZU, Gutierrez A, De Blas AL (1994) The subunit composition of a GABA /benzodiazepine receptor from rat cerebellum. J Neurochem 63:371-374.

Kim HY, Sapp DW, Olsen RW, Tobin AJ (1993) GABA alters GABA receptor mRNAs and increases ligand binding. $J$ Neurochem 61 : 2334-2337.

Konnerth A, Llano I, Armstrong CM (1990) Synaptic currents in cerebellar Purkinje cells. Proc Natl Acad Sci USA 87:2662-2665.

Laufer R, Changeux JP (1989) Activity dependent regulation of gene expression in muscle and neuronal cells. Mol Neurobiol 3:1-54.

Laurie DJ, Seeburg PH, Wisden W (1992) The distribution of 13 GA$\mathrm{BA}_{\mathrm{A}}$ receptor subunit mRNAs in the rat brain. II. Olfactory bulb and cerebellum. J Neurosci 12:1063-1076.

Li HL, Siegel RE, Schwart7. RD (1993) Rapid decline of GABA $_{A}$ receptor subunit mRNA expression in hippocampus following transient cerebral ischemia in the gerbil. Hippocampus 3:527-538.

Llano I, Gerschenfeld HM (1993) Inhibitory synaptic currents in stcllate cells of rat cerebellar slices. J Physiol (Lond) 468:177-200.

Luddens H, Killisch I, Seeburg PH (1991) More than one alpha variant may exist in a $\mathrm{GABA}_{\wedge}$ /benzodiazepine receptor complex. J Recept Res 11:535-551.

Macdonald RL, Olsen RW (1994) GABA receptor channels. Annu Rev Neurosci 17:569-602.

Martin LJ, Blackstone CD, Huganir RL, Price DL (1992) Cellular localization of a metabotropic glutamate receptor in rat brain. Neuron 9:259-270.

Mathews GC, Bolos-Sy AM, Holland KD, Isenberg KE, Covey DF, Ferrendelli JA, Rothman SM (1994) Developmental alteration in $\mathrm{GABA}_{\mathrm{A}}$ receptor structure and physiological properties in cultured cerebellar granule neurons. Neuron 13:149-158.

McKernan RM, Quirk K, Prince R, Cox PA, Gillard NP, Ragan CI, Whiting $P$ (1991) GABA $_{A}$ receptor subtypes immunopurified from rat brain with $\alpha$ subunit-specific antibodies have unique pharmacological properties. Neuron 7:667-676.

Meier E, Drejer J, Schousboe A (1984) GABA induces functionally active low-affinity GABA receptors on cultured cerebellar granule cells. J Neurochem 43:1737-1744.

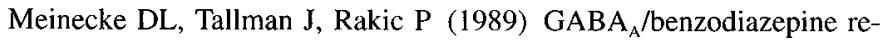
ceptor-like immunoreactivity in rat and monkey cerebellum. Brain Res 493:303-319.

Mertens S, Benke D, Mohler H (1993) GABA receptor populations with novel subunit combinations and drug binding profiles identified in brain by $\alpha 5-$ and $\delta$-subunit-specific immunopurification. $\mathrm{J}$ Biol Chem 268:5965-5973.

Mhatre MC, Pena G, Sieghart W, Ticku MK (1993) Antibodies specific for $\mathrm{GABA}_{\mathrm{A}}$ receptor $\alpha$ subunits reveal that chronic alcohol treatment down-regulates $\alpha$ subunit expression in rat brain regions. J Neurochem 61:1620-1625.

Mody I (1993) The molecular basis of kindling. Brain Pathol 3:395403

Montpied P, Weizman A, Weizman R, Kook KA, Morrow AL, Paul SM (1993) Repeated swim-stress reduces $\mathrm{GABA}_{\mathrm{A}}$ receptor $\alpha$ subunit mRNAs in the mouse hippocampus. Mol Brain Res 18:267-272.

Morrow AL, Herbert JS, Montpied P (1992) Differential effects of chronic ethanol administration on $\mathrm{GABA}_{\mathrm{A}}$ receptor $\alpha 1$ and $\alpha 6$ subunit mRNA levels in rat cerebellum. Mol Cell Neurosci 3:251-258.

Mugnaini E, Oertel WH (1985) An atlas of the distribution of GABAergic neurons and terminals in the rat CNS as revealed by GAD immunohistochemistry. In: Handbook of chemical neuroanatomy (Bjorklund A, Hokfelt T, eds), pp 436-595. Amsterdam: Elsevier.
Naito S, Ueda T (1981) Affinity-purified anti-protein I antibody. J Biol Chem 256:10657-10663.

Nicola MA, Becker CM, Triller A (1992) Development of glycine receptor alpha subunit in cultivated rat spinal neurons: an immunocytochemical study. Neurosci Lett 138:173-178.

Nusser Z, Mulvihill E, Streit P, Somogyi P (1994) Subsynaptic segregation of metabotropic and ionotropic glutamate receptors as revealed by immunogold localisation. Neuroscience 61:421-427.

Nusser Z, Roberts JDB, Baude A, Richards JG, Sieghart W, Somogyi $P$ (1995) Immunocytochemical localisation of the $\alpha 1$ and $\beta 2 / 3$ subunits of the $\mathrm{GABA}_{\mathrm{A}}$ receptor in relation to specific GABAergic synapses in the dentate gyrus. Eur $\mathrm{J}$ Neurosci, in press.

Otis TS, Mody I (1992) Modulation of decay kinetics and frequency of $\mathrm{GABA}_{\mathrm{A}}$ receptor-mediated spontaneous inhibitory postsynaptic currents in hippocampal neurons. Neuroscience 49:13-32.

Ottersen OP, Storm-Mathisen J (1984) Glutamate- and GABA-containing neurons in the mouse and rat brain, as demonstrated with a new immunocytochemical technique. J Comp Neurol 229:374 392.

Ottersen OP, Storm-Mathisen J, Somogyi P (1988) Colocalization of glycine-like and GABA-like immunoreactivities in Golgi cell terminals in the ral cerebellum: a posternbedding light and electron microscopic study. Brain Res 450:342-353.

Persohn E, Malherbe P, Richards JG (1992) Comparative molecular neuroanatomy of cloned $\mathrm{GABA}_{\mathrm{A}}$ receptor subunits in the rat CNS. J Comp Neurol 326:193-216.

Pollard S, Duggan MJ, Stephenson FA (1993) Further evidence for the existence of $\alpha$ subunit heterogeneity within discrete $\gamma$-aminobutyric $\operatorname{acid}_{\mathrm{A}}$ receptor subpopulations. J Biol Chem 268:3753-3757.

Pritchett DB, Sontheimer H, Shivers BD, Ymer S, Kettenmann H, Schofield PR, Seeburg P H (1989) Importance of a novel GABA $A_{A}$ receptor subunit for benzodiazepine pharmacology. Nature 338:582-585.

Puia G, Costa E, Vicini S (1994) Functional diversity of GABA-activated $\mathrm{Cl}^{-}$currents in Purkinje versus granule neurons in rat cerebellar slices. Neuron 12:117-126.

Quirk K, Gillard NP, Ragan CI, Whiting PJ, McKernan RM (1994) Model of subunit composition of $\mathrm{GABA}_{\mathrm{A}}$ receptor subtypes expressed in rat cerebellum with respect to their $\alpha$ and $\gamma / \delta$ subunits. $J$ Biol Chem, 269:16020-16028.

Richards JG, Schoch P, Haring P, Takacs B, Mohler H (1987) Resolving $\mathrm{GABA}_{\mathrm{A}}$ /henzodiazepine receptors: cellular and subcellular localization in the CNS with monoclonal antibodies. J Neurosci 7:18661886.

Sakmann B (1992) Elementary steps in synaptic transmission revealed by currents through single ion channels. Science 256:503-512.

Schoch P, Richards JG, Haring P, Takacs B, Stahli C, Staehelin T, Haefely W, Mohler $\mathrm{H}$ (1985) Co-localization of $\mathrm{GABA}_{\mathrm{A}}$ receptors and benzodiazepine receptors in the brain shown by monoclonal antibodies. Nature 314:168-171.

Schofield PR, Darlison MG, Fujita N, Burt DR, Stephenson FA, Rodriguez $\mathrm{H}$, Rhee LM, Ramachandran J, Reale V, Glencorse TA, Seeburg PH, Barnard EA (1987) Sequence and functional expression of the $\mathrm{GABA}_{\mathrm{A}}$ receptor shows a ligand-gated receptor super-family. Nature 328:221-227.

Sigel E, Baur R, Trube G, Mohler H, Malherbe G (1990) The effect of subunit composition of rat brain $\mathrm{GABA}_{\mathrm{A}}$ receptors on channel function. Neuron 5:703-711.

Soltesz I, Mody I (1994) Patch-clanp recordings reveal powerful GABAergic inhibition in dentate hilar neurons. J Neurosci 14:23652376.

Soltesz 1, Roberts JDB, Takagi H, Richards JG, Mohler H, Somogyi P (1990) Synaptic and nonsynaptic localization of benzodiazepine/GA$\mathrm{BA}_{\mathrm{A}}$ receptor $/ \mathrm{Cl}^{-}$channel complex using monoclonal antibodies in the dorsal lateral geniculate nucleus of the cat. Eur J Neurosci 2:414429.

Somogyi P (1989) Synaptic organization of GABAergic neurons and GABA receptors in the lateral geniculate nucleus and visual cortex. In: Neural mechanisms of visual perception (Lam DK-T, Gilbert CD, eds), pp 35-62. Woodlands, TX: Portfolio.

Somogyi P, Takagi H, Richards JG, Mohler H (1989) Subcellular localization of benzodiazepine/GABA $\mathrm{A}_{\mathrm{A}}$ receptors in the cerebellum of rat, cat, and monkey using monoclonal antibodies. J Neurosci 9:2197-2209.

Spreafico R, De Biasi S, Amadeo A, De Blas AL (1993a) GABA - $^{-}$ receptor immunoreactivity in the rat dorsal thalamus: an ultrastructural investigation. Neurosci Lett 158:232-236. 
Spreafico R, Mennini T, Danuber L, Cagnollo A, Regondi MC, Miari A, De Blas A, Vergnes M, Avanzini G (1993b) GABA $_{A}$ receptor impairment in the genetic absence epilepsy rats from Strasbourg (GAERS): an immunocytochemical and receptor binding autoradiographic study. Epilepsy Res 15:229-238.

Thompson CL, Bodewitz G, Stephenson FA, Turner JD (1992) Mapping of $\mathrm{GABA}_{\mathrm{A}}$ receptor $\alpha 5$ and $\alpha 6$ subunit-like immunoreactivity in rat brain. Neurosci Lett 144:53-56.

Togel M, Mossier B, Fuchs K, Sieghart W (1994) $\gamma$-aminobutyric acid receptors displaying association of $\gamma_{3}$-subunits with $\beta_{2 / 3}$ and different $\alpha$-subunits exhibit unique pharmacological properties. J Biol Chem 269:12993-12998.

Triller A, Cluzeaud F, Pfeiffer F, Betz H, Korn H (1985) Distribution of glycine receptors at central synapses: an immunoelectron microscopy study. J Cell Biol 101:683-688.

Triller A, Cluzeaud F, Pfeiffer F, Korn H (1986) Distribution and transmembrane organization of glycine receptors at central synapses: an immunocytochemical touch. In: Molecular aspects of neurobiology (Montalcini et al., eds), pp 101-105. Berlin: Springer

Triller $\Lambda$, Seitanidou T, Franksson O, Korn H (1991) Use of confocal microscope for the cellular analysis of the glycine synaptic receptor J Recept Res 11:347-357.

Turner JD, Bodewitz G, Thompson CL, Stephenson FA (1993) Im- munohistochemical mapping of gamma-aminobutyric acid type-A receptor alpha subunits in rat central nervous system. In: Anxiolytic $\beta$-carbolines: from molecular biology to the clinic (Stephens DN, ed), pp 29-49. Berlin: Springer.

Verdoorn TA, Draguhn A, Ymer S, Seeburg PH, Sakmann B (1990) Functional properties of recombinant rat $\mathrm{GABA}_{\mathrm{A}}$ receptors depend upon subunit composition. Neuron 4:919-928.

Vincent SR, McIntosh CHS, Buchan AMJ, Brown JC (1985) Central somatostatin systems revealed with monoclonal antibodies. J Comp Neurol 238:169-186.

Waldvogel HJ, Faull RLM, Jansen KLR, Dragunow M, Richards JG, Mohler H, Streit P (1990) GABA, GABA receptors and benzodiazepine receptors in the human spinal cord: an autoradiographic and immunohistochemical study at the light and electron microscopic levels. Neuroscience $39: 361-385$

Yazulla S, Studholme KM, Vitorica J, De Blas AL (1989) Immunocytochemical localization of $\mathrm{GABA}_{\mathrm{A}}$ receptors in goldfish and chicken retinas. J Comp Neurol 280:15-26.

Zezula J, Fuchs K, Sieghart W (1991) Separation of $\alpha_{1}, \alpha_{2}$ and $\alpha_{3}$ subunits of the GABA -benzodiazepine receptor complex by immunoaffinity chromatography. Brain Res 563:325-328.

Zimprich F, Zezula J, Sieghart W, Lassmann H (1991) Immunohistochemical localization of the $\alpha 1, \alpha 2$ and $\alpha 3$ subunit of the GABA receptor in the rat brain. Neurosci Lett 127:125-128 